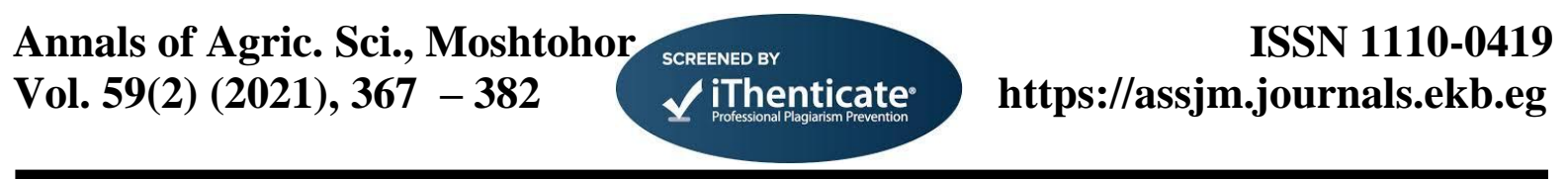

\title{
Manufacturing and Evaluation of a Prototype for Grading of Cereal Corps
}

\author{
Shalaby F. Nasr*, El-Sayed G. Khater**, Adel H. Bahnasawy*** and Hossam M. T. El-Ghobashy**** \\ * Graduate Student of Agric. Eng. Dep., Fac. of Agric., Benha Univ., Egypt \\ ** Associate Professor of Agric. Eng., Fac. of Agric., Benha Univ., Egypt \\ *** Professor of Agric. Eng., Fac. of Agric., Benha Univ., Egypt \\ **** Senior Researcher, Agric. Eng. Res. Inst., Agric. Res. Center, Egypt \\ Corresponding author: alsayed.khater@fagr.bu.edu.eg
}

\begin{abstract}
The main aim of the present study is to develop, fabricate and evaluate a rotating grader for grading cereal corps. The effect of different orifice sizes $(<7.5,7.5$ to 9.5 and 9.5 to $11.0 \mathrm{~mm})$, inclination angles $\left(0,3,5\right.$ and $\left.7^{\circ}\right)$ and rotational speeds of drum $(25,30,35,40,45$ and $50 \mathrm{rpm})$ were studied. The grader productivity, efficiency, specific energy consumption and costs were determined. The obtained results indicated that the grader productivity increased from 11.73 to $49.38,145.72$ to 213.38 and 110.29 to $236.52 \mathrm{~kg} \mathrm{~h}-1$, with increasing orifices size from small to large, inclination angles increased from 0 to $7^{\circ}$ and rotational speed of drum increased from 25 to 50 rpm, respectively. The grader efficiency decreased from 99.00 to $81.89,89.38$ to 87.12 and 89.46 to $86.62 \%$, with increasing orifices size from small to large, inclination angles increased from 0 to $7^{\circ}$ and rotational speed of drum increased from 25 to $50 \mathrm{rpm}$, respectively. The specific energy consumption of grader increased from 10.77 to 13.62 and 9.14 to 14.81 $\mathrm{kW}$ h ton-1, with increasing inclination angles increased from 0 to $7^{\circ}$ and rotational speed of drum increased from 25 to $50 \mathrm{rpm}$, respectively. The total cost of grader decreased from 0.07 to 0.05 and 0.09 to $0.04 \mathrm{EGP} \mathrm{kg}-1$, with increasing inclination angles increased from 0 to $7^{\circ}$ and rotational speed of drum increased from 25 to 50 rpm, respectively.
\end{abstract}

Keywords: Grader, Productivity, Efficiency, Energy, Cost

\section{Introduction}

Maize (corn) is one of the most important cereal crops in the world after wheat and rice. It is called as queen of cereals and king of fodder due to its great importance in human and animal diet. Corn is an important source of carbohydrate, protein, iron, vitamin $\mathrm{B}$ and minerals. It is used in human feeding, industrial aspects for producing, corn oil, starch, syrup, alcohol, acids, and dry food for animal. The global world production of corn exceeded 1.04 Billion ton/year. It is also considered one of the most important grain crops in Egypt. The cultivated area of corn in Egypt is around 1.04 million hectares with total productivity of about 8.06 million ton (FAO, 2014).

Mechanical size grading is a very important process that is associated with a lot of commercial factors, investigating its different methods would be helpful for optimizing relationship between grading efficiency and other different variable factors in these graders, for example, feeding rate, inclination angle and rotational speed. Grading is an important operation affecting quality, handling and storage of produce and plays a major role in the food processing industries. Grading is done to standardize a product, to facilitate marketing, for sales appeal, for ease in quantifying, for ease in price fixing of uniform sized lot and for compliance of international or national grading standards (Thirupathi, 2009).

Dealing with grading in different mechanical methods would be far from researches using automation and electronic methods. In contrast with socalled "automated" grading that is newly adopted in grading houses, simple mechanical graders can be used in anywhere without electrical power source although its inadequacy in other physical grade factors but this review would be on size as a grade factor and different mechanical methods that are used for size orchard crop, for example, rotary sieve graders; rollers that seems relevant to small scale graders (Tayoush, 2018).

Grading of fruits and seeds are considered very important as it can fetch higher price to the grower. Grading also improves packaging, handling and other post-harvest operations. Grading is basically separating the material in different homogenous groups according to its specific characteristics like size, shape, color and on quality basis. It saves time and energy in different processing operations and reduces the handling losses during the transportation. Manual grading is an expensive and time consuming process and even the operation is affected due to nonavailability of labours during peak seasons (Narvankar and Jha, 2005). 
Generally, quality grading includes outer parameters (size, color intensity, color homogeneity, bruises, shape, stem identification surface texture and mass), inner parameters (sweetness, acidity or inner diseases) and freshness. Although, both outer and inner quality information can be collected by an automatic grading system in a factory, but machine vision is more effective for measuring outer parameters (Majumdar and Jayas, 2000, Shahin and Symons, 2001, Paliwal et al., 2003, Shigeta et al., 2004, Shahin et al., 2004, Qiao et al., 2004 and Lorestani et al., 2006). The algorithm can successfully estimate size, sort colour, classify shape, detect bruises or scar tissue and predict the mass of the pepper fruits. Njoroge et al. (2002) described the operations and performance of an automated quality verification system for agricultural products. Kondo et al. (2005) proposed a multi-product grading system for agricultural products.

Cereal grading is a tedious, time consuming and cost operation. Manual grading is expensive and depends on the availability of labor in addition to it is not accurate and its efficiency is very low. Using big and exported graders need high skills and high investment in capital costs which is not possible for small and medium farm. So, the main aim of this work which is to develop, manufacturing and test local grader for cereal which is made from local raw materials, low cost in operating, easy and sample to handle.

\section{Materials and methods}

The experiment was carried out at Ashmoon city, Menoufia Governorate, Egypt, during the period of October and November, 2019 season.

\subsection{Materials: \\ 2.1.1. Machine description}

The designed grader was manufactured in a private workshop at Menoufia Governorate. Figures 1 and 2 show the isometric drawing and the orthographic drawing of the machine. The components of the machine include the machine frame, rotating screens, central shaft, power transmission system and feeding hoper.

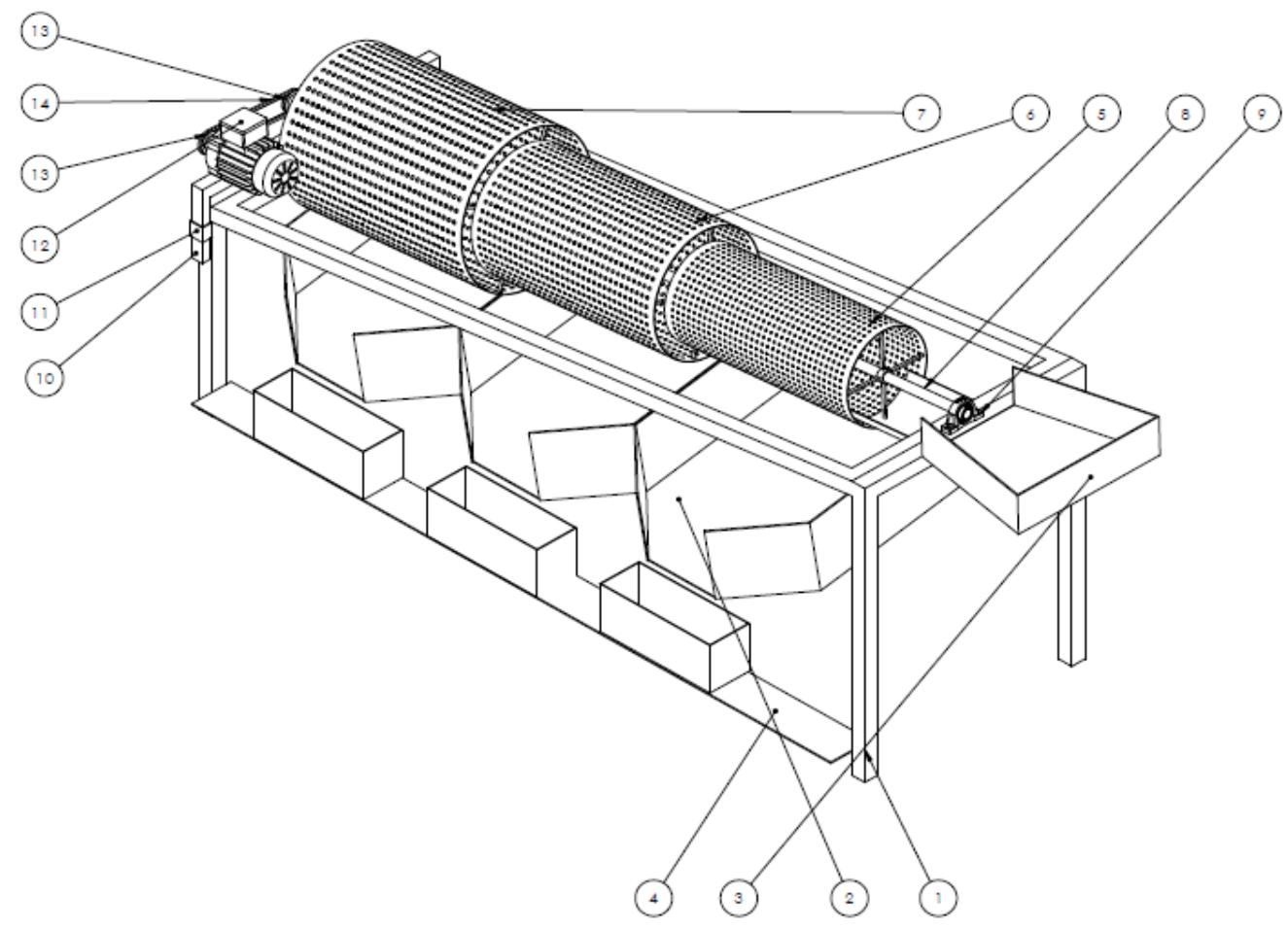

1. Frame

2.Trays supports

3.Feeding hopper

4.metal Rack

5.Rotating screen (A)
Figure (1): Isometric drawing of the grader.

$\begin{array}{ll}\text { 6. Rotating screen (B) } & \text { 11.U-shaped strip } \\ \text { 7. Rotating screen (C) } & \text { 12.Electric motor } \\ \text { 8.Central shaft } & \text { 13.Belt } \\ \text { 9.Hopper support } & \text { 14.cover }\end{array}$

10.Shaft free side base 


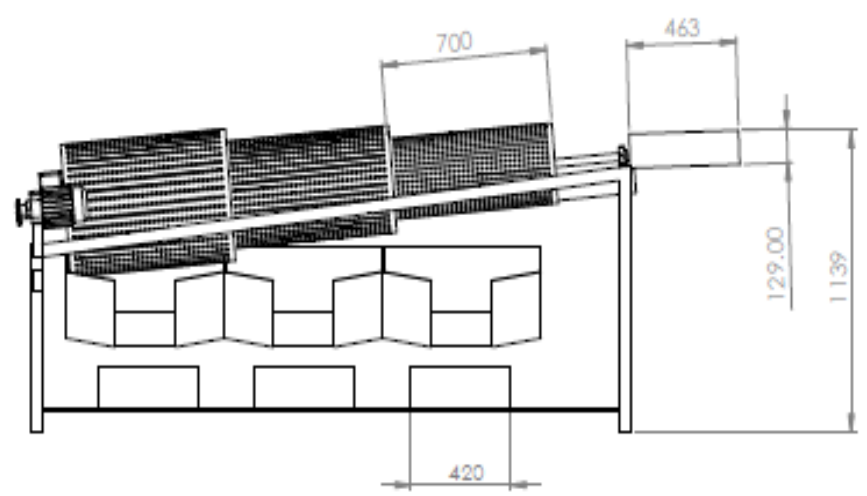

Elevation

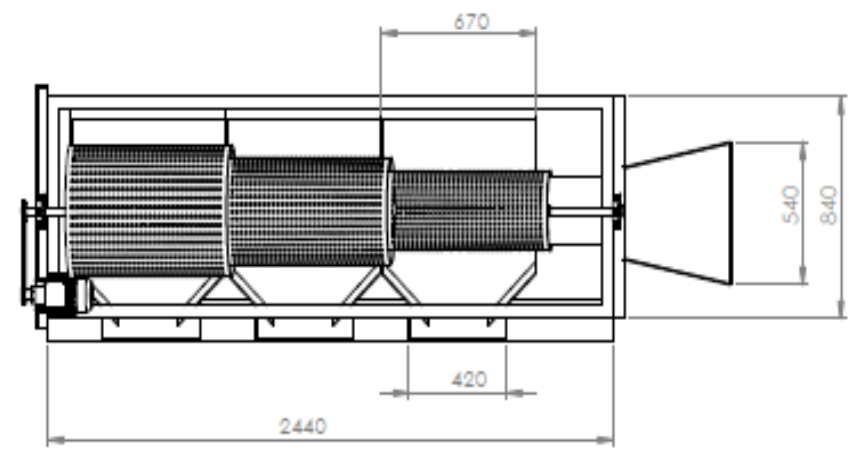

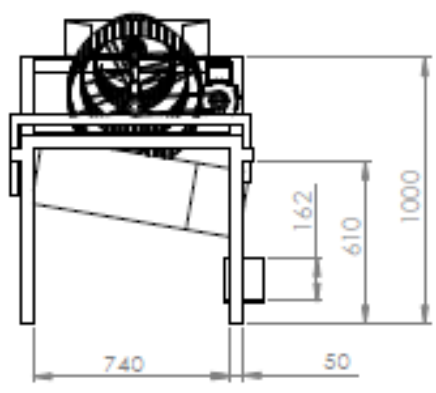

Side View

Plan

Figure (2): Orthographic drawing of the grader.

\subsubsection{Rotating screens:}

Grading system was consisting of three perforated rotary drums (rotating screens) to grade corn cereals samples into three grades and this could be achieved by passing corn seeds through these screens, the first drum was designed for small volume seeds. The higher size seeds are going to continue to the second drum to be sized as a second grade and the largest seeds will be sized as the third grade and any other seeds that pass over the third stage without sizing due to its dimensions that did not fit opening dimensions to be able to pass onto, it would be considered as a fourth grade. Every drum was made up of a rectangular mild steel sheet with a thickness of 2 $\mathrm{mm}$. Then the sheets were perforated according to each grade and folded together and welded to form a drum as shown in figure (3). The main structure of rotating screen with a total length of $210 \mathrm{~cm}$ which consists of three perforated rotary drums with a similar length of $70 \mathrm{~cm}$ and hole diameters of 30,40 and $50 \mathrm{~cm}$ for first, second and third grade drum, respectively. 


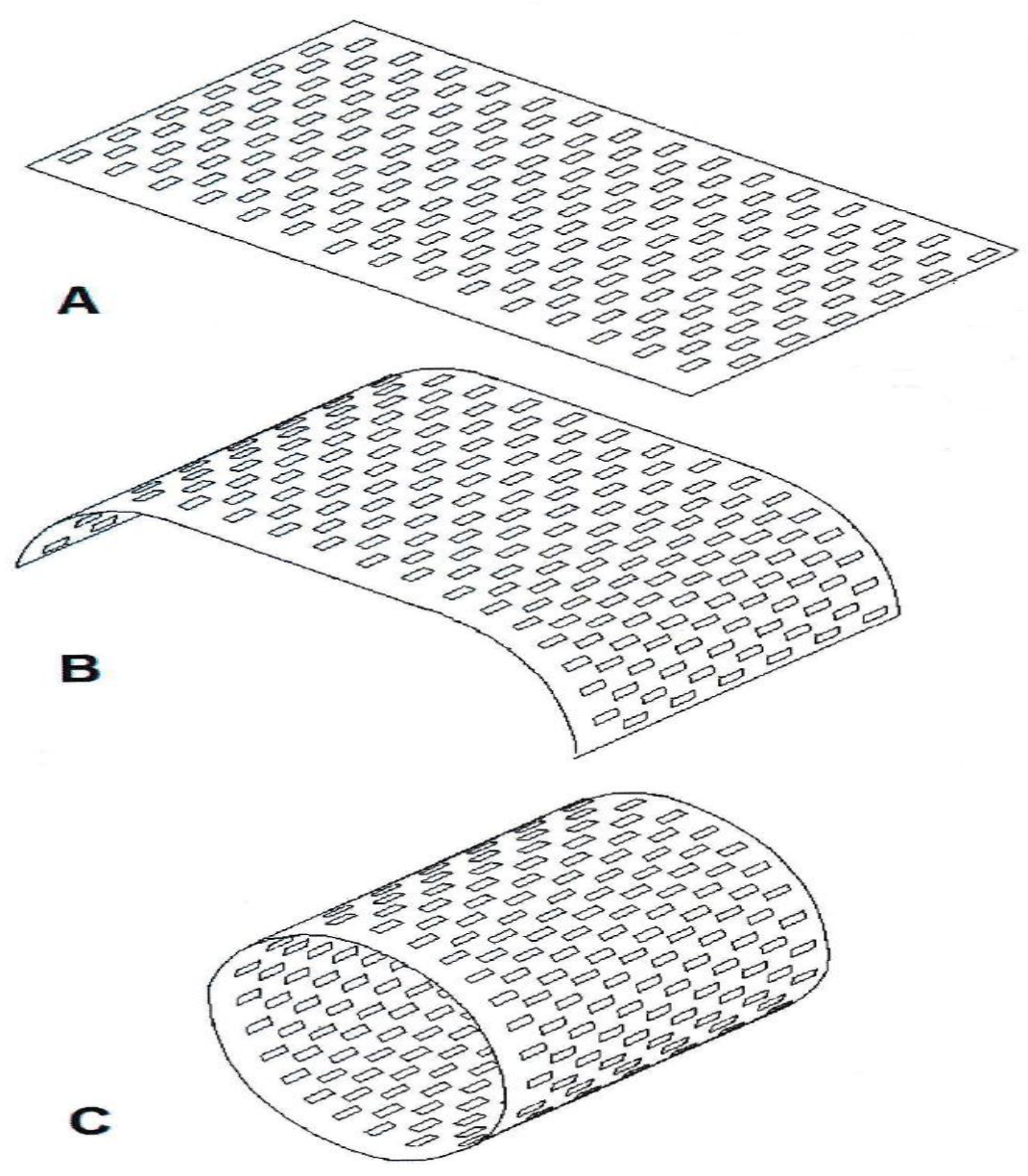

Figure (4): Schematic arrangement of rotating screens.

A: Cutting and perforating sheets according to each grade, B: Gathering the two sides of sheet, C: Welding them to form a drum

\subsubsection{Central shaft:}

Perforated drums were gathered using a central shaft running through the entire length of rotating screens, it was made from a mild steel rod with an external and internal diameter of 2 and $1.5 \mathrm{~cm}$, respectively and with a length of $240 \mathrm{~cm}$ connected to four crossed-shape $10 \mathrm{~mm}$ diameter steel rods by cylindrical rings have been furnished to be through of it (figure 4). The shaft is supplying drums with power for a rotational movement. The two ends of the shaft have been mounted on the frame using two pushed bearings (figure 5). 


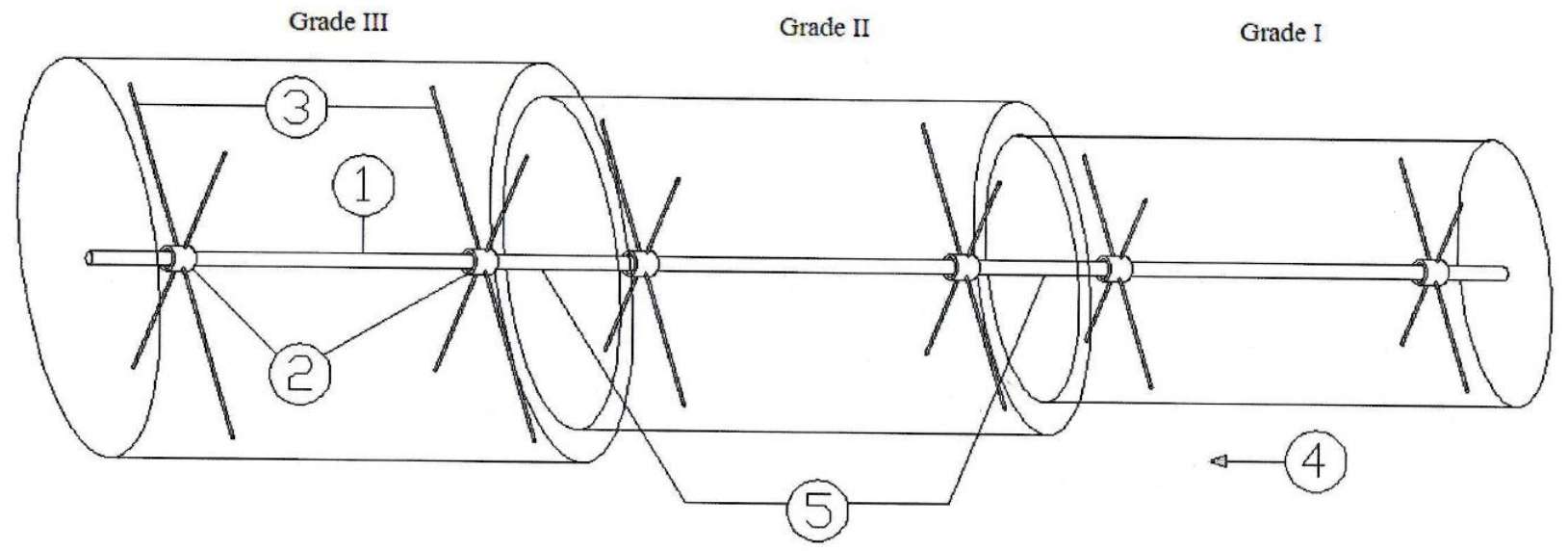

Figure (4): Schematic drawing of central shaft for gathering, fixing and supplying drums with power.

1. Central shaft, 2. Cylindrical rings, 3. Mid steel rods (crossed shape), 4. Seeds travel direction, and 5. Overlapping zones.

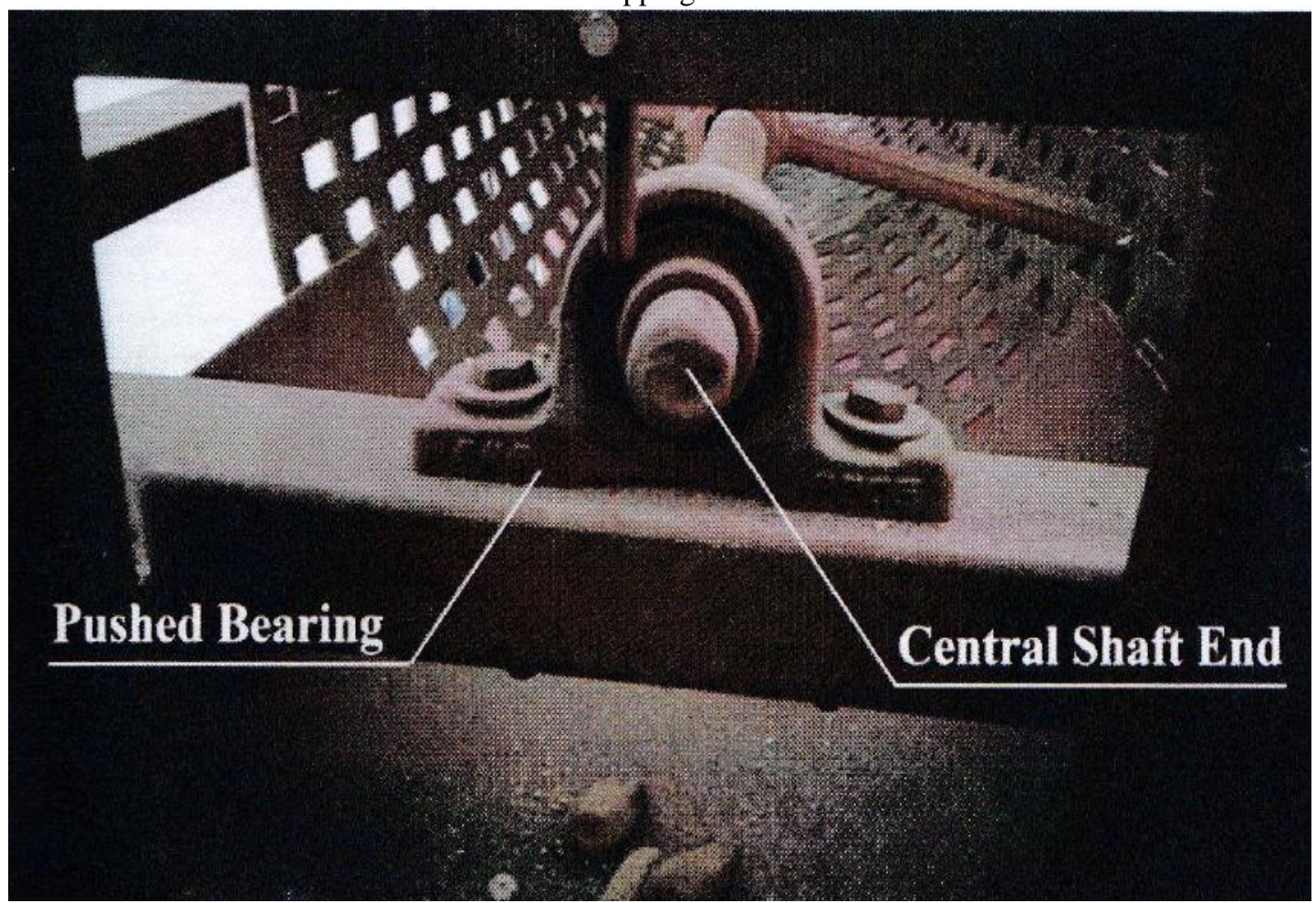

Figure (5): Image of the pushed bearing used for mounting the central shaft on frame.

\subsubsection{Screens fixed system to the central shaft:}

Screens have been fixed to the rod using bolts and nuts fixed on small cylindrical rings. These rings are allowing rod to go through of it and also connected to the drums by four crossed shape $10 \mathrm{~mm}$ mild steel rods as shown in figures 6 and 7 by these rings, perforated rotating screens would be operated due to their connection with the central shaft that is responsible about operating including rotational motion and this could happen by tying bolts with nuts for ensuring that the central shaft and drums are a one unit. 


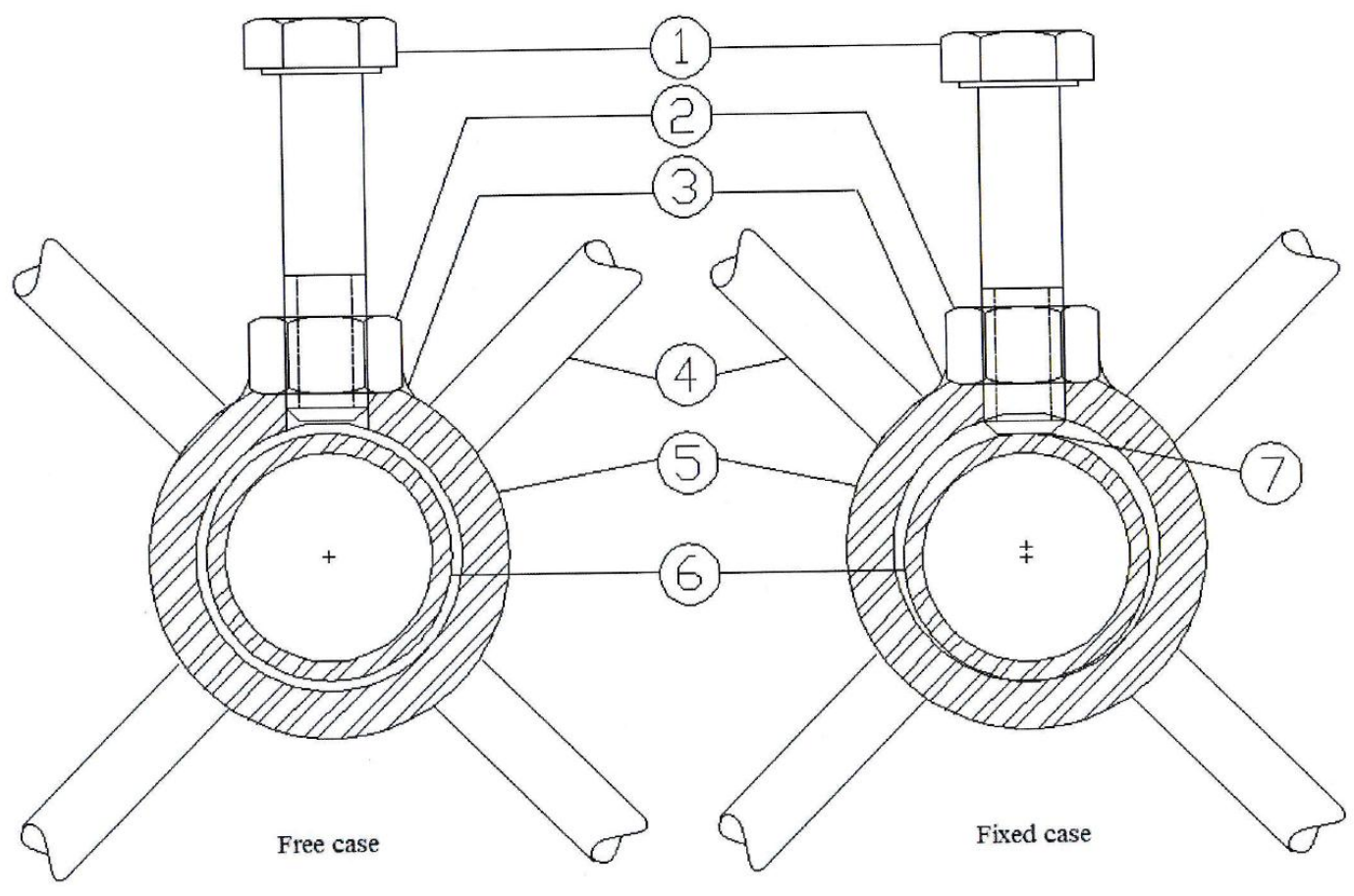

Figure (6):

Drums fixing system to the central axial rod.

1. Bolt, 2. Nuts, 3. Welding points, 4. Rods connecting to drums, 5. Cylindrical rings, 6. Axial rod gathering drum, and 7. Fixing point.

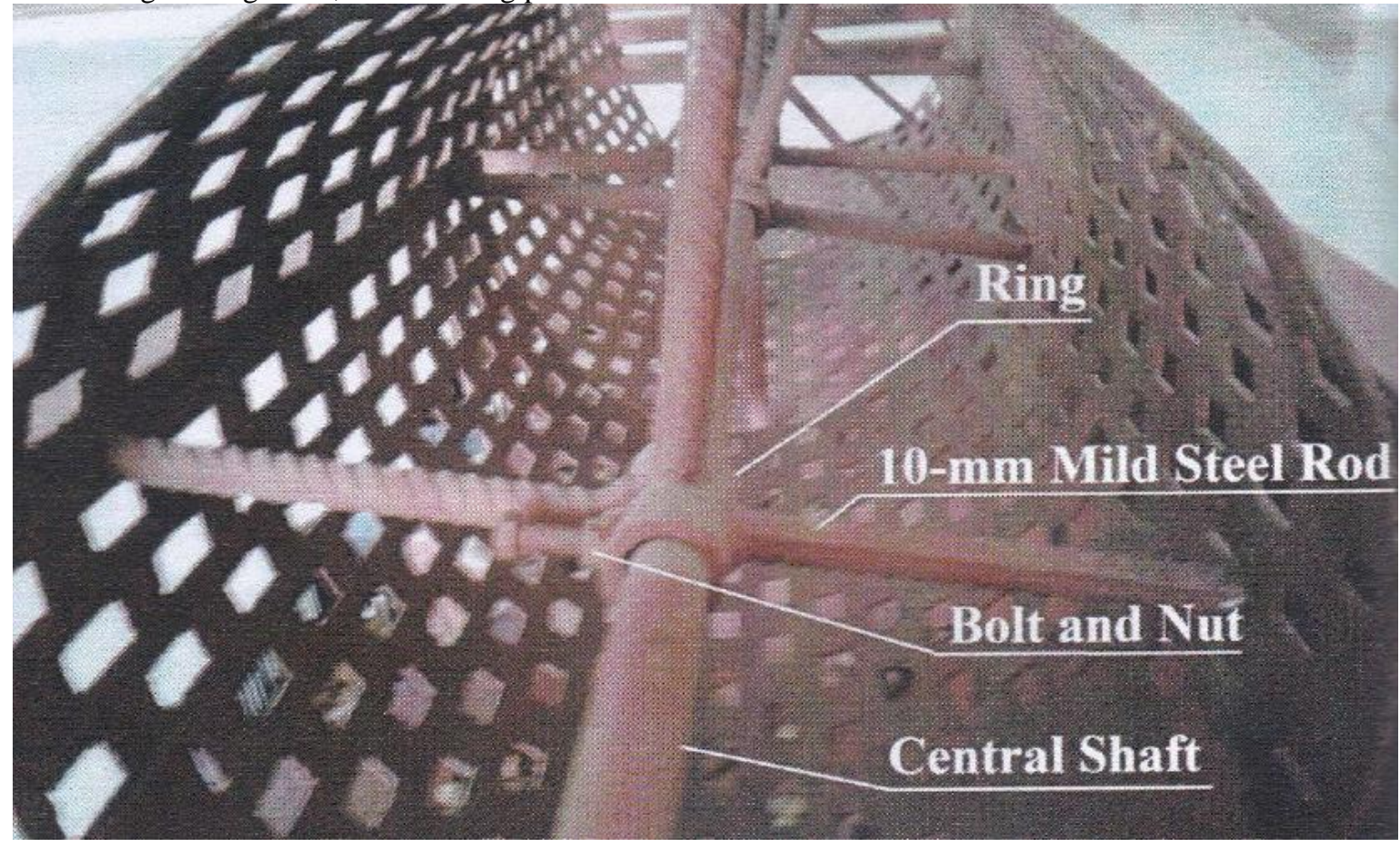

Figure (7): Image of drum fixing system to the central shaft.

2.1.1.4. Power transmission system and rotational speed changing methods:

The machine is driven by single phase electric motor (Model GAMAK -Power 1 hp 220V 50Hz, Turkey) and it was installed on a mild steel plate using bolts and nuts on a base made up of $4 \times 2 \mathrm{~cm}$ mild steel rectangular sections so in case of changing inclination angle of rotating screen, motor and screen will move as a one unit. The power was transmitted to the screen by two pulleys, one of them was fitted to the motor and 
the other one fitted to the central shaft and there is a belt transmitting power from the electric motor to the screen (figure 8). The speed of motor is $1400 \mathrm{rpm}$. To change rotational speed of rotating screen, inverter was

used to control the electricity input of the motor (model IP65 (IEC-60529) NEMA-4 and 220v 50/60Hz 2hp KWAIT).

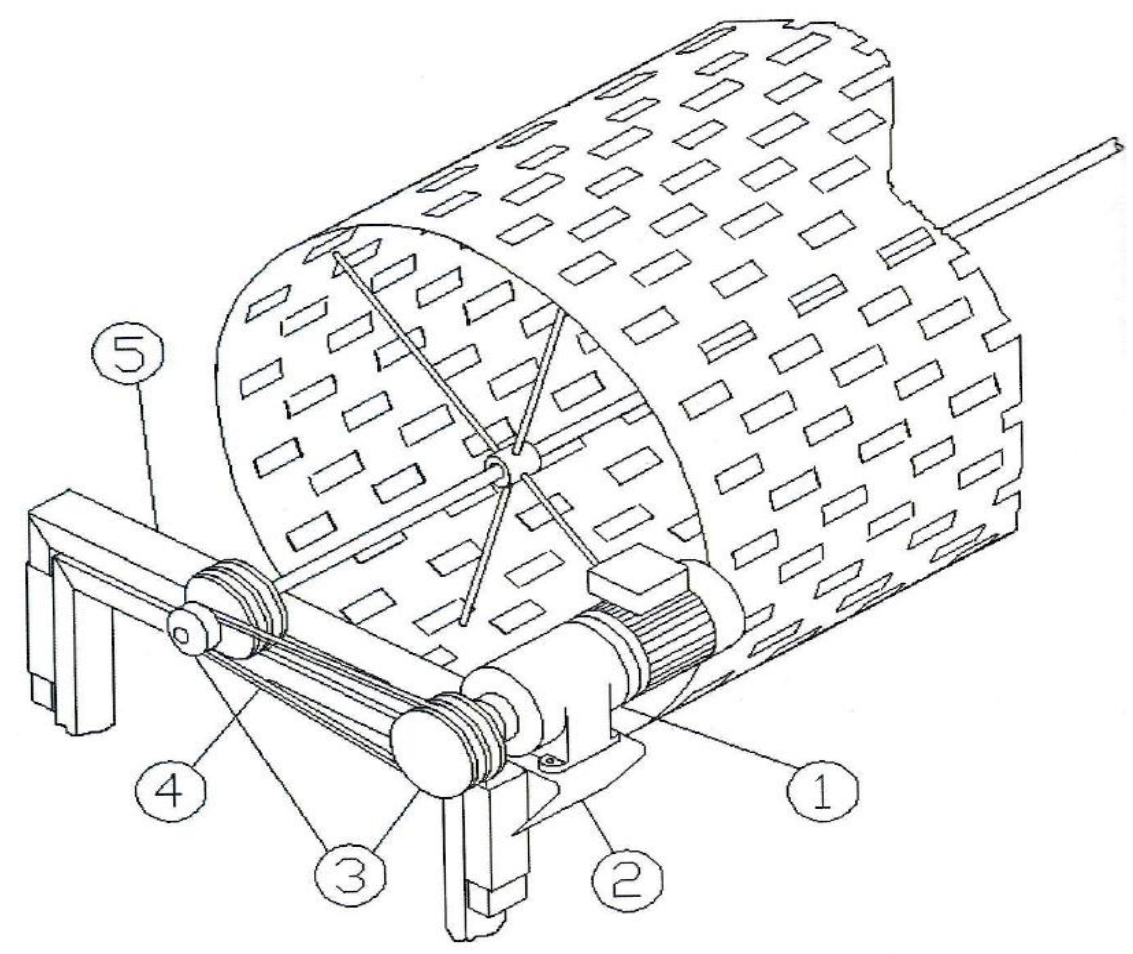

Figure (8): Power transmission apparatus.

1. Electric motor, 2. Base for fixing motor, 3. Pulley, 4. V-type belt and 5. Base fixing the central shaft to rotate freely and adjusting its slope.

2.1.1.5. Screen inclination angle and its adjusting technique:

One of the most important factors affecting grading efficiency is the screen inclination angle because low slope levels could be a reason of reducing grader grading efficiency, it could be prevent seeds from moving forward to be graded and high slope levels could prevent seeds from taking its time to be graded due to the high speeds of seeds that are moving forward and consequently would be at the end of the screen grader without grading. Adjusting slope system was designed to be simple. One of the two ends of the central shaft was fixed on the machine chassis and the other end was fixed on a free rectangular section mild steel base as shown in figure (9), using a screw-jack was fixed and running through the frame for raising or lowering the base that is lifting both of electric motor and the other side of the central shaft at discharge end. This base moves vertically in a track which is Ushaped strip attached to the two edges of the frame (Uedging) for more stability during adjusting inclination angle. 


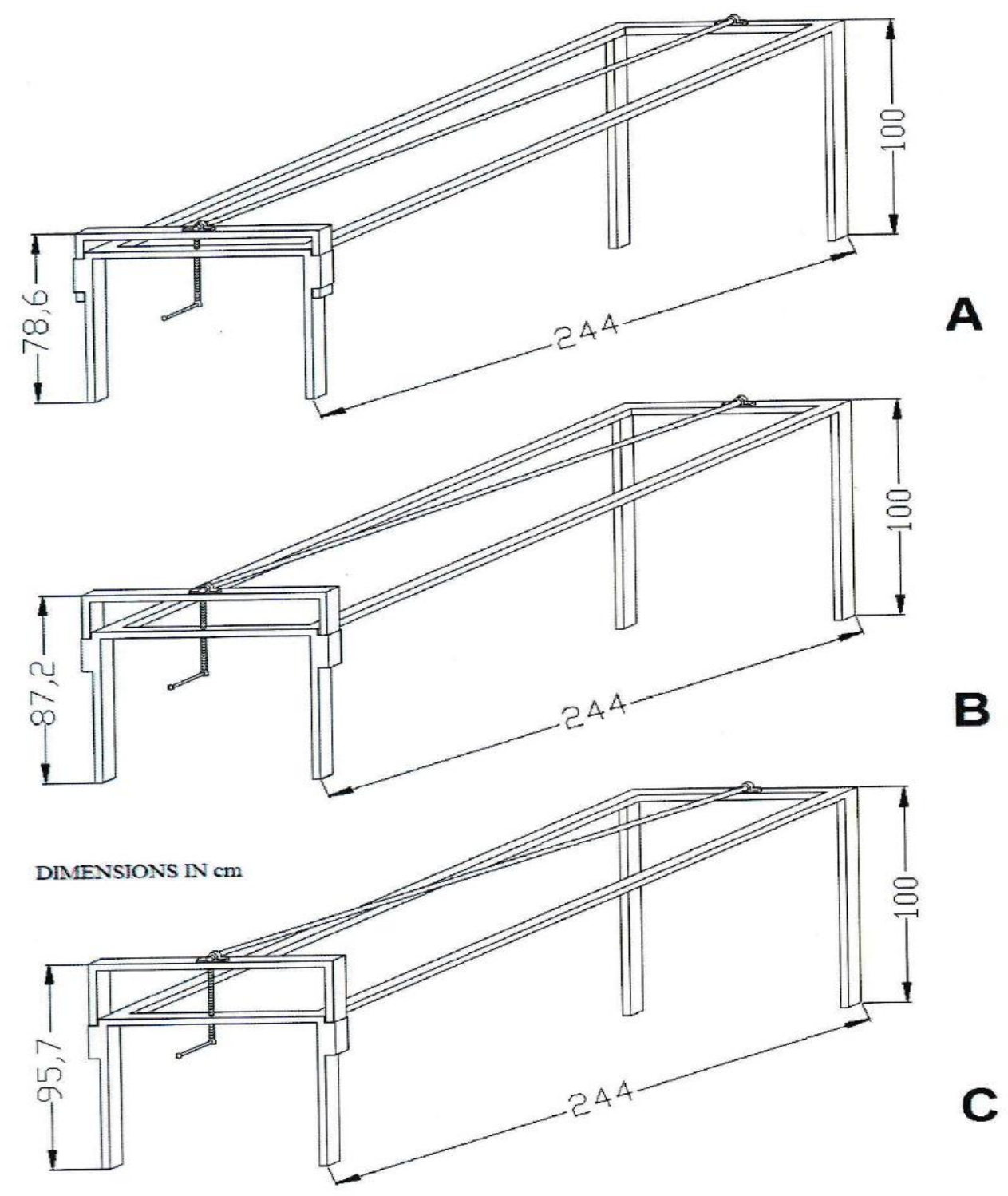

Figure (9): Schematic arrangement of the different heights for the free side of central shaft using screw-jack for reaching different inclination angles of rotational screen drum.

\subsubsection{Feeding hoper:}

Feeding system was made up of mild steel welded to grader body on the same integrity, it has the same inclination angle of the longitudinal bars in upper part of the frame, also, it was supplied with a gate moving in a track could be lifted or lower using a handle welded to it and could be used for controlling feeding rate but during experiment gate was removed to facilitate feeding rate adjustment (figure 10). Hoper supplied with two supports (mild steel L-section $2 \times 2$ $\mathrm{cm}$ ). Feeding process was carried out manually by pushing corn seeds through the gate to reach a mild steel feeding tray takes the shape of a horizontal cylindrical segment welded to the frame and it supplies the screen with corn seeds. 


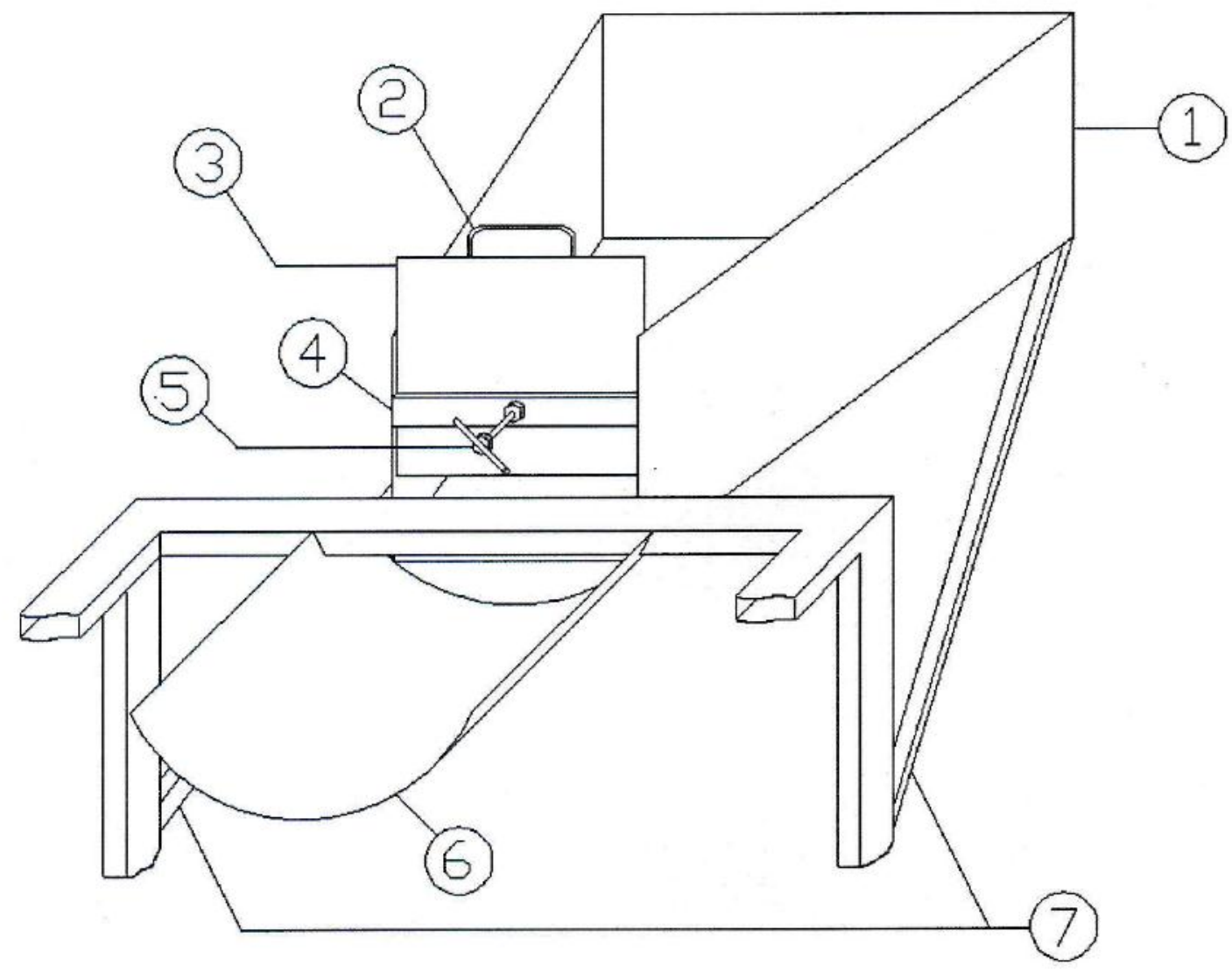

Figure (10): Schematic drawing of feeding hopper.

1. Feeding hopper, 2. Handle, 3. Gate, 4. Gate track, 5. Bolt with a handle, 6. Cylindrical segment tray, and 7. Mild steel L-section for supporting hopper.

\subsection{Methods:}

The developed rotating grader was evaluated by studying the effect of perforated orifice size, inclination angle and rotational speed of screen on the productivity, efficiency and energy requirements of grader.

2.2.1. Experimental design:

The treatments were arranged in a split-split plot design in three replications. The treatments include: three perforated orifice sizes are $<7.5,7.5$ to 9.5 and 9.5 to $11.0 \mathrm{~mm}$, four inclination angles are 0,3 , 5 and $7^{\circ}$ and six rotational speeds of drum are 25, 30, $35,40,45$ and $50 \mathrm{rpm}$ with feeding rate of $15 \mathrm{~kg}$.

2.2.2. Measurements:

2.2.2.1. Grader productivity:

The grader productivity (kg h-1) was determined as the amount of the corn cereals graded during operation time.

2.2.2.2. Grader efficiency:

Grader efficiency was determined from equation (1):

$$
\eta_{G}=\frac{M o}{M i} \times 100
$$

Where:

$\eta \mathrm{G}$ is the grader efficiency, $\%$

Mo is the mass of cereals of each class after grading, $\mathrm{kg}$

$\mathrm{Mi}$ is the total mass of cereals before grading, $\mathrm{kg}$

2.2.2.3. Power and energy requirement for grader

The power requirement $(\mathrm{W})$ was estimated by using the clamp meter to measure the line current strength (I) and the potential difference value (V).

The total electric power requirement under machine working load $(\mathrm{P})$ was calculated according to Kurt (1979) by the following equation:

$$
P=\sqrt{3} \times I \times V \times \cos \theta
$$

Where:

$\mathrm{P}$ is the power requirement to grader, $\mathrm{W}$

I is the line current strength, Amperes.

$\mathrm{V}$ is the potential difference, Voltage.

$\operatorname{Cos} \theta$ is the power factor, equal 0.8 .

The specific energy consumption (SEC) in $\mathrm{W}$ $\mathrm{h} \mathrm{kg-1}$ was calculated by using the following equation: 


$$
S E C=\frac{P}{\operatorname{Pr}_{\text {actual }}}
$$

Where:

$\mathrm{SEC}$ is the specific energy consumption, $\mathrm{W} \mathrm{h} \mathrm{kg}$ -

Practual is the actual productivity, $\mathrm{kg} \mathrm{h}-1$

\subsection{Total Costs}

The cost calculation based on the following parameters was also performed:

2.3.1. Fixed costs $(\mathrm{Fc})$ :

- Depreciation costs (Dc):

$$
D_{c}=\frac{P_{d}-S_{r}}{L_{d}}
$$

Where:

Dc is the depreciation cost, EGP (Egyptian pound) year-1.

$\mathrm{Pd}$ is the corn seed grader purchase price, 12000 EGP.

$\mathrm{Sr}$ is the salvage rate $(0.1 \mathrm{Pd}) \mathrm{EGP}$.

Ld is the grader life, 5 year.

- Interest costs (In):

$$
I_{n}=\frac{P_{d}+S_{r}}{2} \times \mathrm{i}_{\mathrm{n}}
$$

Where:

In is the interest, EGP year-1.

in is the interest as compounded annually, decimal. (12\%)

- $\quad$ Shelter, taxes and insurance costs (Si):

Shelter, taxes and insurance costs were assumed to be $3 \%$ of the purchase price of the grader (Pm).

Then:

Fixed cost $\left(\mathrm{EGP} \mathrm{h}^{-1}\right)=\mathrm{Dc}+\mathrm{In}+0.03 \mathrm{Pm} /$ hour of use per year

Variable (operating) costs ( Vc):

- Repair and maintenance costs (Rm):

$R m=100 \%$ deprecation cost / hour of use per year

- Energy costs $(\mathrm{E})$ :

$$
E=\mathrm{EC} \times \mathrm{EP}
$$

Where:

$\mathrm{E}$ is the energy costs, EGP h-1.

$\mathrm{EC}$ is the electrical energy consumption, $\mathrm{kWh}$. $\mathrm{EP}$ is the energy price, $0.57 \mathrm{EGP} \mathrm{kW}-1$.

- $\quad$ Labor costs (La):

$$
L a=\text { Salary of one worker } \times \text { No. of workers }
$$

Where:

La is the Labor costs, EGP h-1.

Salary of one worker $=10$ EGP h-1.

No. of workers $=1$

Then:

Variable costs $\left(\mathrm{EGPh}^{-1}\right)=\mathrm{R}_{\mathrm{m}}+\mathrm{E}+\mathrm{La}$

2.3.3. Total costs (Tc):

Total cost $\left(\mathrm{EGPh}^{-1}\right)=$ Fixed cost $\left(\mathrm{EGPh}^{-1}\right)+$ Variable cost $\left(\mathrm{EGP}^{-1}\right)$

\section{Results and Discussion:}

2.4. Grader productivity:

Table (1) and figures (11, 12 and 13) show the productivity of grading corn cereals as affected by the orifice sizes from small $(<7.5 \mathrm{~mm})$ to large $(9.5$ to 11.0 $\mathrm{mm})$, the inclination angles from 0 to $7^{\circ}$ and rotational speeds of screw drum from 25 to $50 \mathrm{rpm}$. The results indicate that the grader productivity increases with increasing orifice size, inclination angle and drum speed. It indicates that when the orifice size increased from 7.5 to $11.0 \mathrm{~mm}$, the machine productivity increased from 11.73 to 49.38 (by 76.24 increment percent) $\mathrm{kg} \mathrm{h}-1$. It also indicates that when the inclination angle increased from 0 to $7^{\circ}$, the machine productivity increased from 145.72 to 213.38 (by 31.71 increment percent) $\mathrm{kg} \mathrm{h}-1$, while the machine productivity increased from 110.29 to 236.52 (by 53.37 increment percent) $\mathrm{kg} \mathrm{h}-1$ when the rotational speed increased from 25 to $50 \mathrm{rpm}$.

It could be noticed that increasing the orifice size from small $(<7.5 \mathrm{~mm})$ to large $(9.5-11.0 \mathrm{~mm})$, tends to increase the machine productivity from 7.48 to

(7) $309.21,9.69$ to $406.36,11.28$ to $472.12,12.77$ to $534.27,14.19$ to 611.36 and 14.98 to $664.66 \mathrm{~kg} \mathrm{~h}-1$ at $25,30,35,40,45$ and $50 \mathrm{rpm}$ rotational speeds, respectively. The results also indicate that the machine productivity increased from 7.48 to $14.98,14.18$ to 29.92 and 309.12 to $664.66 \mathrm{~kg} \mathrm{~h}-1$ at small $(<7.5 \mathrm{~mm})$, medium ( 7.5 to $9.5 \mathrm{~mm}$ ) and large (9.5 to $11.0 \mathrm{~mm})$ orifice sizes, respectively when the rotational speed increased from 25 to $50 \mathrm{rpm}$ as shown in figure 11 . The trend of these results agreed with those obtained by Tayoush (2018). 
Table 1. Grader productivity at different orifice sizes, inclination angles and rotational speeds of screen drum.

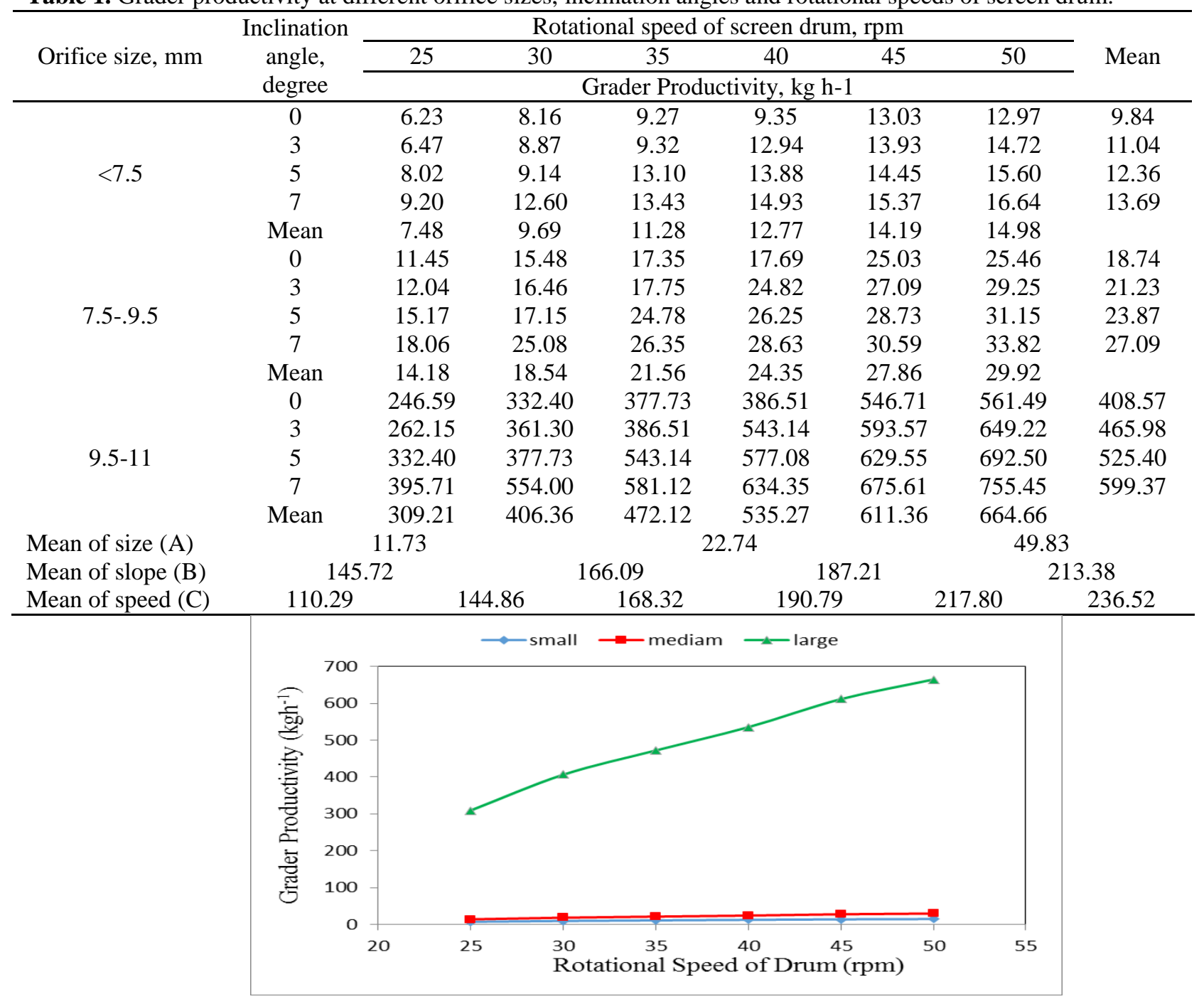

Fig. 11. Machine productivity at different orifice sizes and inclination angles.

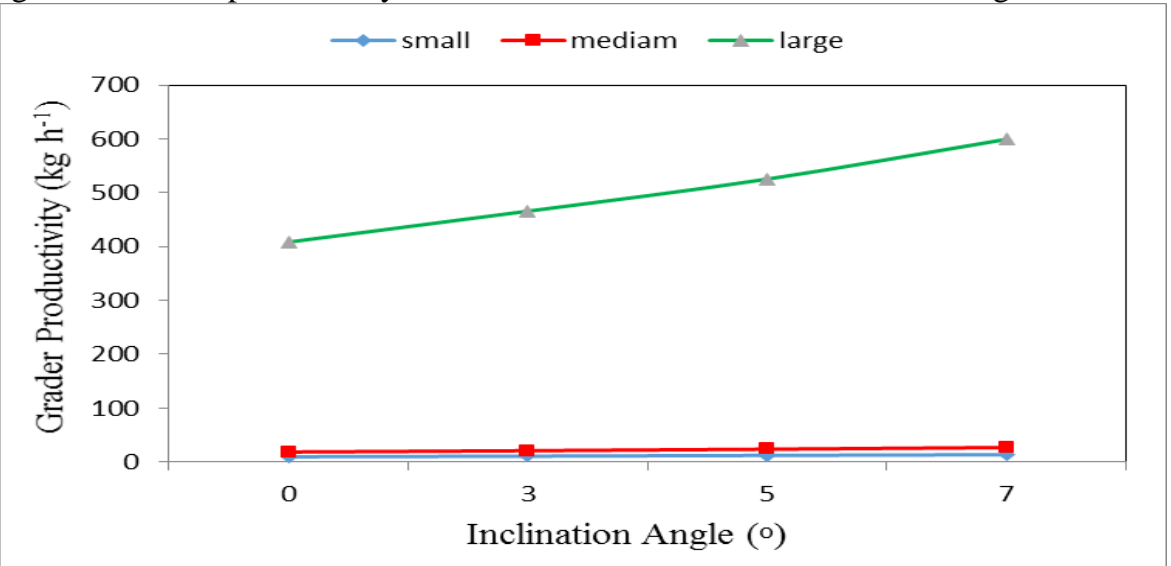

Fig. 12. Machine productivity at different orifice sizes and rotational speeds of drum. 


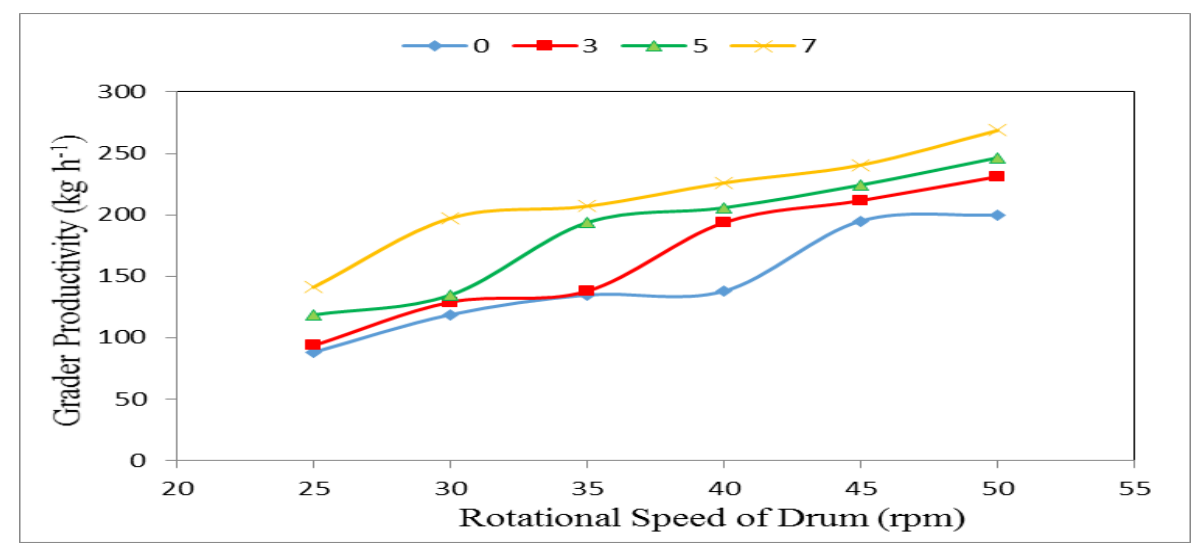

Fig. 13. Machine productivity at different inclination angles and rotational speeds of drum.

Regarding the effect of orifice size and inclination angle on the machine productivity, the results indicate that the machine productivity increases with increasing the orifice size and inclination angle. It increased from 9.84 to $408.57,11.04$ to $465.98,12.36$ to 525.40 and 13.69 to $566.37 \mathrm{~kg} \mathrm{~h}-1$ at $0,3,5$ and $7^{\circ}$ inclination angle, respectively, when the orifice size increased from small $(<7.5 \mathrm{~cm})$ to large $(9.5$ to 11.0 $\mathrm{cm})$. The results also indicate that the machine productivity increased from 9.84 to $13.69,18.74$ to 27.09 and 408.57 to $599.37 \mathrm{~kg} \mathrm{~h}-1$ at small $(<7.5 \mathrm{~cm})$, medium $(7.5$ to $9.5 \mathrm{~cm})$ and large $(9.5$ to $11.0 \mathrm{~cm})$, respectively, when the inclination angle increased from 0 to $7^{\circ}$ as shown in figure 12 .

The results also indicate that the machine productivity increased from 88.09 to $140.99,118.68$ to $197.23,134.78$ to $206.67,137.85$ to $225.97,194.92$ to 240.52 and 199.97 to $268.64 \mathrm{~kg} \mathrm{~h}-1$ at $25,30,35,40$, 45 and $50 \mathrm{rpm}$ rotational speed, respectively, when the inclination angles increased from 0 to $7^{\circ}$. The results also indicate that the machine productivity increased from 88.09 to $199.97,93.55$ to $231.06,118.53$ to 246.42 and $268.64 \mathrm{~kg} \mathrm{~h}-1$ at $0,3,5$ and $7^{\circ}$ inclination angles, respectively, when the rotational speed increased from 25 to $50 \mathrm{rpm}$ as shown in figure 13 .

Multiple regression analysis was carried out to obtain a relationship between the grader productivity as dependent variable and different inclination angles and rotational speeds as independent variables. The best fit for this relationship is presented in the following equation:-

$$
P=-44.82+9.59 I A+4.99 R S \quad \mathrm{R}^{2}=0.87
$$

Where: seeds, $\mathrm{kg} \mathrm{h}-1$

$\mathrm{P}$ is the grader productivity for grading corn

IA is the inclination angle, degree

$\mathrm{RS}$ is the rotational speed of drum, rpm

This equation could be applied in the range of 0 to $7^{\circ}$ inclination angle and from 25 to $50 \mathrm{rpm}$ of rotational speed of drum.

\subsection{Grader efficiency:}

Table (2) and figures (14, 15 and 16) show the grader efficiency as affected by the orifice size from small $(<7.5 \mathrm{~mm})$ to large $(9.5$ to $11.0 \mathrm{~mm})$, the inclination angle from 0 to $7^{\circ}$ and rotational speed of drum from 25 to $50 \mathrm{rpm}$. The results indicate that the grader efficiency decreases with increasing orifice size, inclination angle and drum speed. It indicates that when the orifice size increased from small to large, the machine efficiency decreased from 99.00 to 81.89 (by 17.28 reduction percent) $\%$. It also indicates that when the inclination angle increased from 0 to $7^{\circ}$, the machine efficiency decreased from 89.38 to 87.12 (by 2.45 reduction percent) $\%$, while the machine efficiency decreased from 89.46 to 86.62 (by 3.17 reduction percent) $\%$ when the rotational speed increased from 25 to $50 \mathrm{rpm}$.

It could be noticed that increasing the orifice size from small $(<7.5 \mathrm{~mm})$ to large $(9.5-11.0 \mathrm{~mm})$, tends to increase the machine efficiency from 84.25 to $99.44,82.48$ to $99.22,83.08$ to $99.07,82.72$ to 98.91 , 80.57 to 98.96 and 78.23 to $98.02 \%$ at $25,30,35,40$, 45 and $50 \mathrm{rpm}$ rotational speeds, respectively. The results also indicate that the machine efficiency decreased from 84.25 to $78.23,84.74$ to 83.04 and 99.44 to $98.02 \%$ at small $(<7.5 \mathrm{~cm})$, medium $(7.5$ to $9.5 \mathrm{~cm})$ and large $(9.5$ to $11.0 \mathrm{~cm})$ orifice sizes, respectively when the rotational speed increased from 25 to $50 \mathrm{rpm}$ as shown in figure 14 . 
Table 2. Grader efficiency at different orifice sizes, inclination angles and rotational speeds of screw.

\begin{tabular}{|c|c|c|c|c|c|c|c|c|}
\hline \multirow{3}{*}{ Orifice size, mm } & \multirow{3}{*}{$\begin{array}{c}\text { Inclination } \\
\text { angle, } \\
\text { degree }\end{array}$} & \multicolumn{6}{|c|}{ Rotational speed of screen drum, rpm } & \multirow{3}{*}{ Mean } \\
\hline & & 25 & 30 & 35 & 40 & 45 & 50 & \\
\hline & & \multicolumn{6}{|c|}{ Grader Efficiency, \% } & \\
\hline \multirow{5}{*}{$<7.5$} & 0 & 87.50 & 85.00 & 85.00 & 83.73 & 82.56 & 80.03 & 83.97 \\
\hline & 3 & 85.5 & 84.97 & 83.73 & 82.53 & 81.36 & 78.56 & 82.78 \\
\hline & 5 & 83.50 & 81.20 & 83.57 & 83.20 & 79.50 & 78.10 & 81.51 \\
\hline & 7 & 80.50 & 78.73 & 80.00 & 81.53 & 78.86 & 76.23 & 79.31 \\
\hline & Mean & 84.25 & 82.48 & 83.08 & 82.75 & 80.57 & 78.23 & \\
\hline \multirow{5}{*}{$7.5-.9 .5$} & 0 & 85.70 & 86.00 & 84.77 & 84.50 & 84.57 & 83.30 & 84.81 \\
\hline & 3 & 84.77 & 84.17 & 84.73 & 84.37 & 84.20 & 83.13 & 84.23 \\
\hline & 5 & 84.30 & 83.80 & 84.30 & 84.00 & 84.20 & 83.10 & 83.95 \\
\hline & 7 & 84.20 & 83.60 & 83.77 & 83.37 & 83.57 & 82.63 & 83.52 \\
\hline & Mean & 84.74 & 84.39 & 84.39 & 84.06 & 84.14 & 83.04 & \\
\hline \multirow{5}{*}{$9.5-11$} & 0 & 99.82 & 99.54 & 99.51 & 99.29 & 99.14 & 99.00 & 99.38 \\
\hline & 3 & 99.55 & 99.37 & 99.13 & 99.10 & 99.08 & 98.90 & 99.19 \\
\hline & 5 & 99.37 & 99.28 & 99.12 & 99.00 & 98.86 & 98.72 & 99.06 \\
\hline & 7 & 99.03 & 98.70 & 98.53 & 98.26 & 98.77 & 97.87 & 98.53 \\
\hline & Mean & 99.44 & 99.22 & 99.07 & 98.91 & 98.96 & 98.62 & \\
\hline Mean of size $(\mathrm{A})$ & \multicolumn{3}{|c|}{99.00} & \multicolumn{3}{|c|}{84.13} & \multicolumn{2}{|c|}{81.89} \\
\hline Mean of slope (B) & \multicolumn{2}{|c|}{89.39} & \multicolumn{2}{|c|}{88.73} & \multicolumn{2}{|c|}{88.17} & \multicolumn{2}{|c|}{87.12} \\
\hline Mean of speed (C) & \multicolumn{2}{|c|}{89.46} & 88.68 & 88.83 & \multicolumn{2}{|c|}{88.56} & 87.87 & 86.62 \\
\hline
\end{tabular}

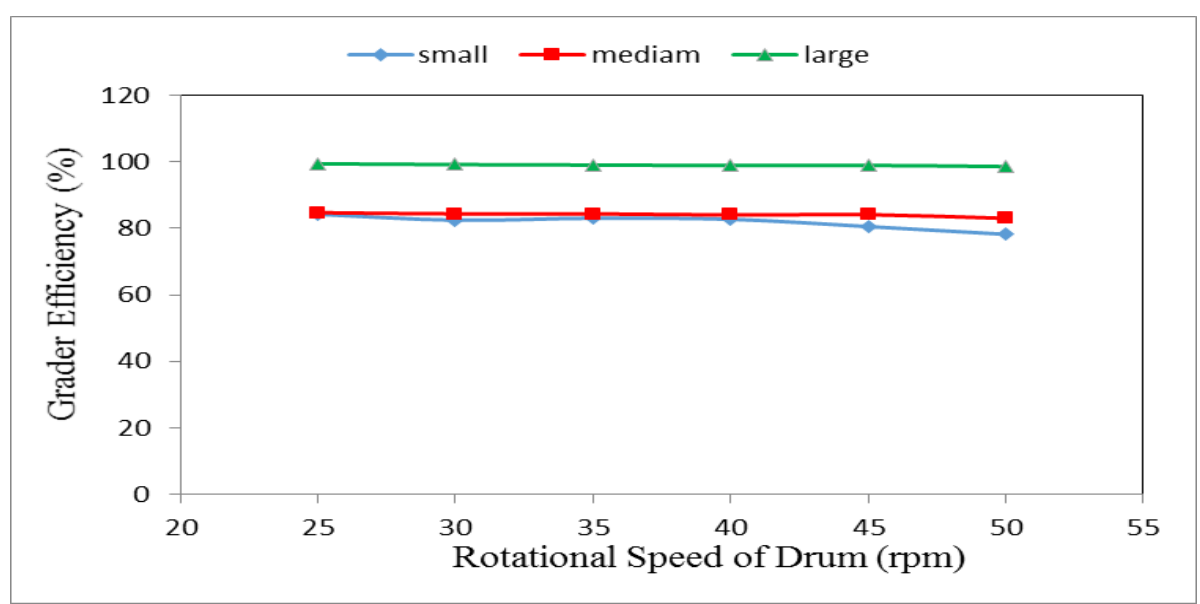

Fig. 14. Grader efficiency at different orifice sizes and inclination angles.

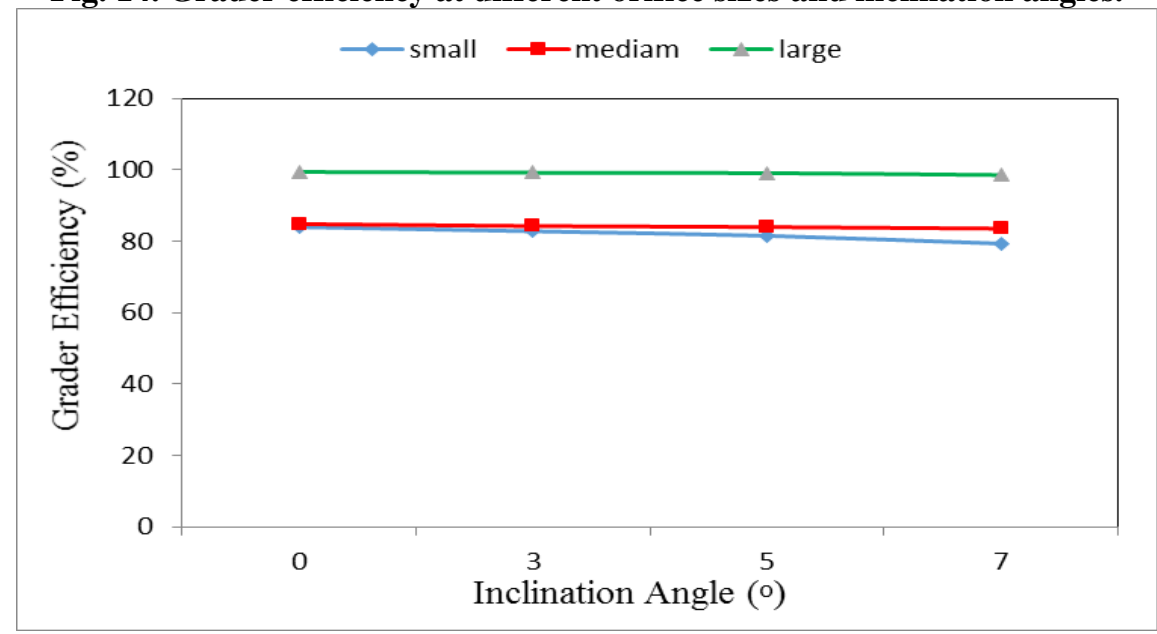

Fig. 15. Grader efficiency at different orifice sizes and rotational speeds of drum. 


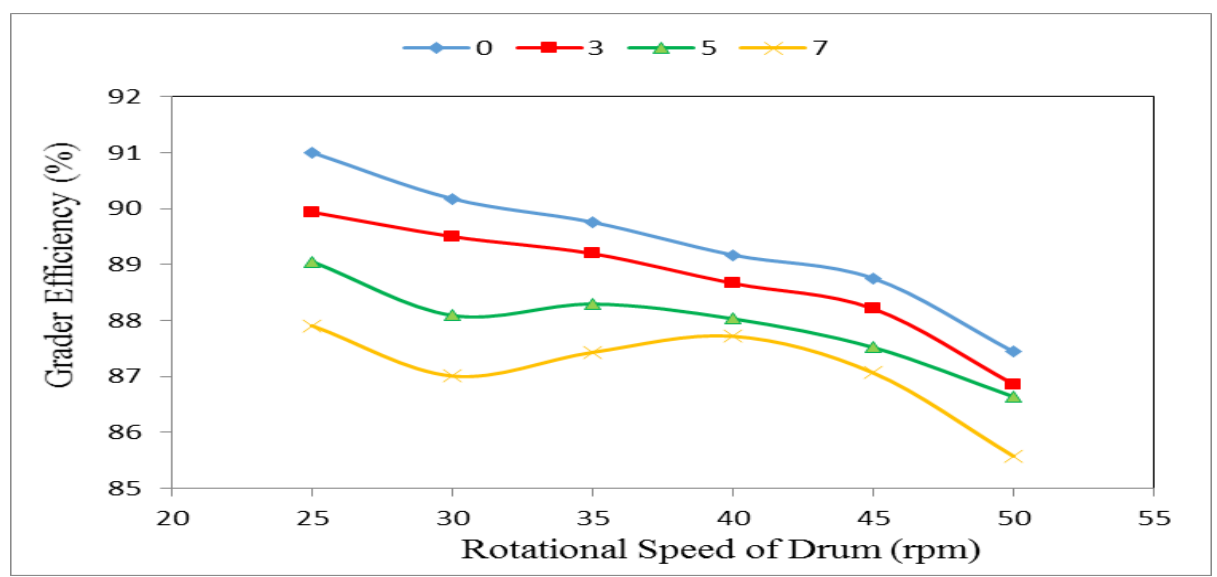

Fig. 16. Grader efficiency at different inclination angles and rotational speeds of drum.

Multiple regression analysis was carried out to obtain a relationship between the grader efficiency as dependent variable and different both of inclination angle and rotational speed as independent variables. The best fit for this relationship is presented in the following equation:-

$$
\eta_{G}=90.81-0.52 I A-0.03 R S \quad \mathrm{R}^{2}=0.89
$$

Where:

$\eta \mathrm{G}$ is the grader efficiency for grading corn seeds, $\mathrm{kg} \mathrm{h}-1$

This equation could be applied in the range of 0 to $7^{\circ}$ inclination angle and from 25 to $50 \mathrm{rpm}$ of rotational speed of drum.

2.6. Specific energy consumption:

Figure (17) shows the specific energy consumption for grading corn seeds as affected by the inclination angle from 0 to $7^{\circ}$ and rotational speed of drum from 25 to $50 \mathrm{rpm}$. The results indicate that the specific energy consumption for grading corn seeds increases with increasing inclination angle and drum speed. It indicates that when the inclination angle increased from 0 to $7^{\circ}$, the mean of specific energy consumption for grading corn seeds increased from 10.77 to 13.62 (by $20.93 \%$ ) $\mathrm{kW} \mathrm{h}$ ton-1, while the mean of specific energy consumption for grading corn seeds increased from 9.14 to 14.81 (by $38.28 \%$ ) $\mathrm{kW} \mathrm{h}$ ton-1 when the rotational speed increased from 25 to $50 \mathrm{rpm}$.

The results also indicate that the specific energy consumption for grading corn seeds increased from 8.58 to $9.68,9.17$ to $10.95,9.85$ to $13.34,12.10$ to $14.82,12.15$ to 15.82 and 12.66 to $17.10 \mathrm{~kW} \mathrm{~h}$ ton- 1 at $25,30,35,40,45$ and $50 \mathrm{rpm}$ rotational speed, respectively, when the inclination angles increased from 0 to $7^{\circ}$. The results also indicate that the specific energy consumption for grading corn seeds increased from 8.58 to $12.66,8.95$ to $13.98,9.36$ to 15.51 and 9.68 to $17.10 \mathrm{~kW}$ h ton- 1 at $0,3,5$ and $7^{\circ}$ inclination angles, respectively, when the rotational speed increased from 25 to $50 \mathrm{rpm}$.

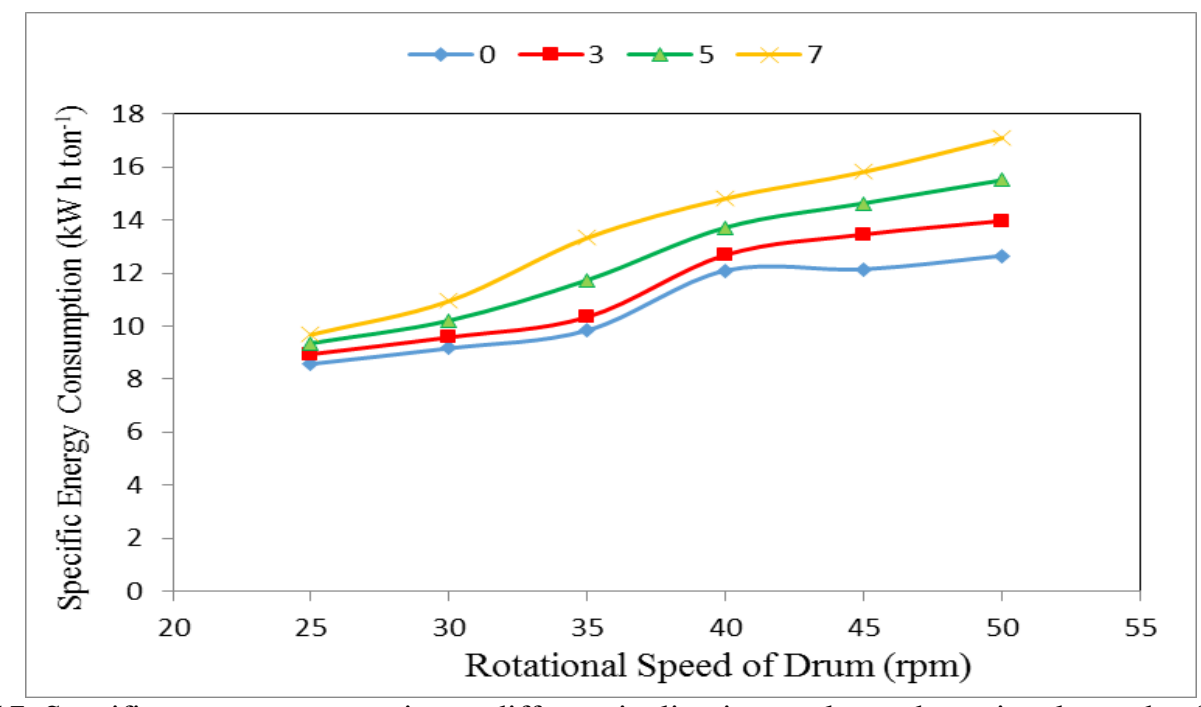

Fig. 17. Specific energy consumption at different inclination angles and rotational speeds of drum. 
Multiple regression analysis was carried out to obtain a relationship between the specific energy consumption as dependent variable and different inclination angles and rotational speeds as independent variables. The best fit for this relationship is presented in the following equation:-

$S C E=1.45+0.41 I A+0.24 R S$

$$
\mathrm{R}^{2}=0.94
$$

This equation could be applied in the range of 0 to $7^{\circ}$ inclination angle and from 25 to $50 \mathrm{rpm}$ of rotational speed of drum.

\subsection{Total cost:}

Table (3) shows the total cost for grading corn seeds as affected by the inclination angle from 0 to $7^{\circ}$ and rotational speed of drum from 25 to $50 \mathrm{rpm}$. The results indicate that the total cost for grading corn seeds decreases with increasing inclination angle and drum speed. It indicates that when the inclination angle increased from 0 to $7^{\circ}$, the mean of total cost for grading corn seeds decreased from 0.07 to 0.05 (by $28.57 \%$ ) EGP kg-1, while the mean of total cost for grading corn seeds decreased from 0.09 to 0.04 (by $55.56 \%$ ) EGP kg-1 when the rotational speed increased from 25 to $50 \mathrm{rpm}$.

The results also indicate that the total cost for grading corn seeds decreased from 0.11 to $0.07,0.08$ to $0.05,0.07$ to $0.05,0.07$ to $0.04,0.05$ to 0.04 and 0.05 to 0.04 EGP $\mathrm{kg}-1$ at $25,30,35,40,45$ and $50 \mathrm{rpm}$ rotational speed, respectively, when the inclination angles increased from 0 to $7^{\circ}$. The results also indicate that the total cost for grading corn seeds decreased from 0.11 to $0.05,0.10$ to $0.04,0.08$ to 0.04 and 0.07 to 0.04 EGP $\mathrm{kg}-1$ at $0,3,5$ and $7^{\circ}$ inclination angles, respectively, when the rotational speed increased from 25 to $50 \mathrm{rpm}$.

Table 3. Total cost at different inclination angles and rotational speeds of drum.

\begin{tabular}{cccccccc}
\hline \multirow{2}{*}{$\begin{array}{c}\text { Inclination } \\
\text { angle, degree }\end{array}$} & \multicolumn{7}{c}{ Rotational speed of screen drum, rpm } \\
\cline { 2 - 7 } Mean & Total Cost, EGP kg-1 \\
\hline 0 & 25 & 30 & \multicolumn{7}{c}{35} & 0.07 & 0.05 & 0.05 & 0.07 \\
3 & 0.11 & 0.08 & 0.07 & 0.05 & 0.05 & 0.04 & 0.06 \\
5 & 0.10 & 0.07 & 0.07 & 0.05 & 0.04 & 0.04 & 0.05 \\
7 & 0.08 & 0.07 & 0.05 & 0.04 & 0.04 & 0.04 & 0.05 \\
Mean & 0.09 & 0.05 & 0.05 & 0.05 & 0.04 & 0.04 & \\
\hline
\end{tabular}

Multiple regression analysis was carried out to obtain a relationship between the total cost as dependent variable and different inclination angles and rotational speeds as independent variables. The best fit for this relationship is presented in the following equation:-

$$
T C=0.139-0.003 I A-0.002 R S \quad \mathrm{R}^{2}=0.84
$$

Where:

TC is the total cost for grading corn seeds, EGP kg -1

This equation could be applied in the range of 0 to $7^{\circ}$ inclination angle and from 25 to $50 \mathrm{rpm}$ of rotational speed of drum.

\section{Conclusion}

The experiment was carried out to study is to develop, fabricate and evaluate a grader for grading corn cereal. To achieve that study the effect of different orifice sizes $(<7.5,7.5$ to 9.5 and 9.5 to $11.0 \mathrm{~mm})$, inclination angles $\left(0,3,5\right.$ and $\left.7^{\circ}\right)$ and rotational speeds of drum $(25,30,35,40,45$ and $50 \mathrm{rpm})$ on the grader productivity, efficiency, specific energy consumption and costs. The obtained results can be summarized as follows:

- The grader productivity increased from 11.73 to $49.38 \mathrm{~kg} \mathrm{~h}-1$, when the orifices size increased from small to large, respectively. It increased from
145.72 to $213.38 \mathrm{~kg} \mathrm{~h}-1$, when the inclination angle increased from 0 to $7^{\circ}$. While, it increased from 110.29 to $236.52 \mathrm{~kg} \mathrm{~h}-1$ when the rotational speed of drum increased from 25 to $50 \mathrm{rpm}$.

- The grader efficiency decreased from 99.00 to $81.89 \%$, when the orifices size increased from small to large, respectively. It decreased from 89.38 to $87.12 \%$, when the inclination angle increased from 0 to $7^{\circ}$. While, it decreased from 89.46 to $86.62 \%$ when the rotational speed of drum increased from 25 to $50 \mathrm{rpm}$.

- The of specific energy consumption for grading corn seeds increased from 10.77 to $13.62 \mathrm{~kW} \mathrm{~h}$ ton1 , when the inclination angle increased from 0 to $7^{\circ}$, while the specific energy consumption for grading corn seeds increased from 9.14 to $14.81 \mathrm{~kW} \mathrm{~h}$ ton-1 when the rotational speed increased from 25 to 50 rpm.

- The total cost for grading corn seeds decreased from 0.07 to $0.05 \mathrm{EGP} \mathrm{kg}-1$, when the inclination angle increased from 0 to $7^{\circ}$, while the total cost for grading corn seeds decreased from 0.09 to 0.04 EGP kg-1 when the rotational speed increased from 25 to $50 \mathrm{rpm}$. 


\section{References}

Shahin, M.A., Symons S.J. and Meng A.X. (2004). Seed Sizing with Image Analysis. ASAE paper No. 043121

Shigeta, K., Motonaga Y., Kida T. and Matsuo M. (2004). Distinguishing damaged and undamaged chaff in rice whole crop silage by image processing. ASAE Annual Meeting. Paper No. 043125.

Shahin, M.A. and Symons S.J. (2001). A machine vision system for grading lentils. Can. Biosys. Eng. 7: 7-14.

Qiao, J., Sasao A., Shibusawa S., Kondo N. and Morimoto E. (2004). Mobile fruit grading robot (Part I)- development of a robotics system for grading sweet pepper. J. Jpn. Soc. Agric. Mach. 66(2): 113-122.

Paliwal, J., Borhan M.S. and Jayas D.S. (2003). Classification of cereal grains using a flatbed scanner. ASAE paper No. 036103.

Majumdar, S. and Jayas D.S. (2000). Classification of cereal grains using machine vision: II- Color models. ASAE 43(6): 1677-1680.

Njoroge, J.B., Ninomiya K., Kondo N. and Toita H. (2002). Automated fruit grading system using image processing. Proceedings of the 41st SICE Annual Conference. 2(5-7): 1346-1351.
Kondo, N., Ninomiya K., Peter R., Kamata J. and Fasil A. (2005). Development of Multi-Product Grading System, ASAE Annual Meeting, paper No. 043125.

Lorestani, A.N., Omid M., Shooraki S.B., Borghei A.M. and Tabatabaeefar A. (2006). Design and evaluation of a Fuzzy Logic based decision support system for grading of Golden Delicious apples. Int. J. Agric. Biol. 8(4): 440-444.

Narvankar, D.S. and Jha S.K. (2005). Development of rotating screen grader for selected orchard crops. Journal of Agricultural Engineering, 42 (4).

Ashraf, M., Muhammad S., Manzoor A. and Muhammad Y. (2007). Design, development and performance evaluation of fruit and vegetable grader. Pakistan Journal of Agricultural Science, 44(4).

FAO (Food and Agriculture Organization) (2014). The State of Food and Agriculture. Innovation in family farming. Food and Agriculture Organization of the United Nations, Rome, 2014.

Tayoush, A.A. (2018). Study on grading dates "Manufacturing and evaluation of prototype for grading of dates on volume basis". M. Sc. Thesis, Fac. Agric., Kafrelsheikh Univ., Egypt.

Thirupathi, V. (2009). Performance Evaluation of a Divergent Roller Grader for Selected Vegetables. Journal of Agricultural Mechanization in Asia, Africa, and Latin America, 40 (4), 60-62.

$$
\begin{aligned}
& \text { تصنيع وتقييم نموذج لتدريج محاصيل الحبوب }
\end{aligned}
$$

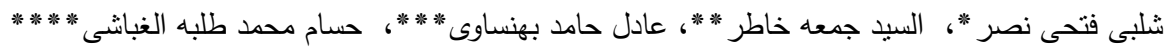

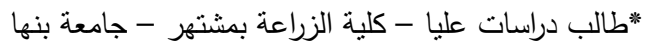

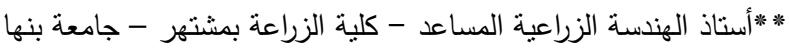

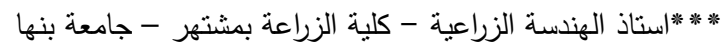

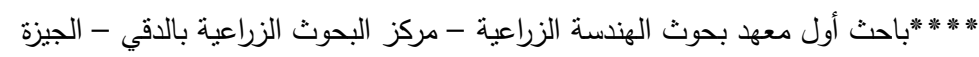

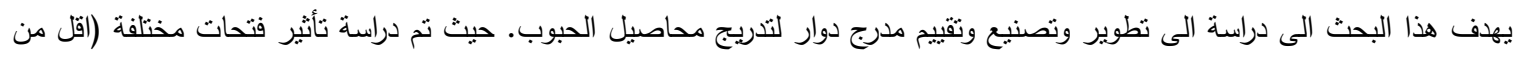

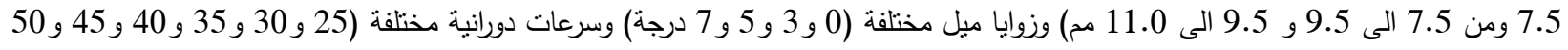

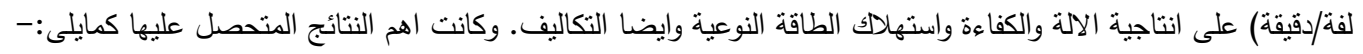

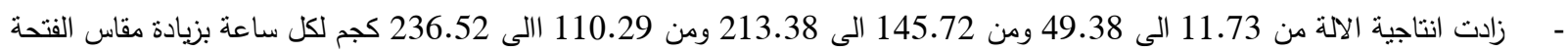

$$
\begin{aligned}
& \text { من الصغيرة الى الكبيرة وزيادة زاوية الميل من } 0 \text { الى } 7 \text { درجات وزيادة السرعة الدورانية للاوام من } 25 \text { الى } 80 \text { الى } 50 \text { لفة/دقيقة. }
\end{aligned}
$$

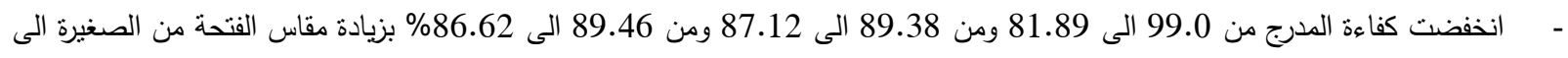

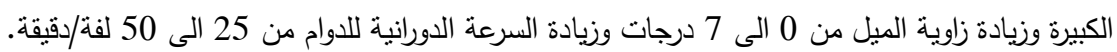

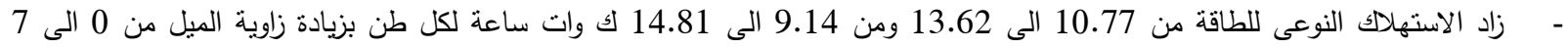

$$
\begin{aligned}
& \text { درجات وزيادة السرعة الدورانية للدوام من } 25 \text { الى } 50 \text { لفة الفئدقيقة. } \\
& \text { - انخفضت تكاليف النتغيل الكلية من } 0.07 \text { الى } 0.05 \text { ومن } 0.09 \text { الى } 0.04 \text { جنية لكل كجم بزيادة زاوية الميل من } 0 \text { الى } 7 \text { درجات وزيادة } \\
& \text { السرعة الدورانية للاوام من } 25 \text { الى } 50 \text { لفة/دقيقة. }
\end{aligned}
$$

